ZOOLOGIA 31 (6): 521-524, December, 2014

http://dx.doi.org/10.1590/S1984-46702014000600001

\title{
Length-weight relationships and prediction equations of body composition of farm raised Astyanax aff. fasciatus (Actinopterygii: Characiformes: Characidae)
}

\author{
Valéria R.B. Furuya ${ }^{1,3}$, Mariana Michelato², Thais P. da Cruz ${ }^{1} \&$ Wilson M. Furuya ${ }^{1}$ \\ ${ }^{1}$ Departamento de Zootecnia, Universidade Estadual de Ponta Grossa. Avenida Carlos Cavalcanti 4748, \\ 84030-900 Ponta Grossa, PR, Brazil. \\ 2 Programa de Pós-graduação em Zootecnia, Universidade Estadual de Maringá. Avenida Colombo 5790, \\ 87020-900 Maringá, PR, Brazil. \\ ${ }^{3}$ Corresponding author. E-mail: vrbfuruya@uepg.br
}

\begin{abstract}
This study ascertains the length-weight relationship and predicts body composition equations in cultivated Astyanax aff. fasciatus. A total of 300 fish were distributed in five groups according to body weight: $1.19 \pm 0.18,3.7 \pm$ $0.70,7.55 \pm 0.97,12.28 \pm 2.32$ and $22.16 \pm 2.64 \mathrm{~g}$. The length-weight relationship was elaborated using linear $\left(y_{i}=\beta_{0}\right.$ $\left.+\beta_{1} x_{i}\right)$ or second-order $\left(y_{i}=\beta_{0}+\beta_{1} x_{i}+\beta_{1} x_{i}^{2}\right)$ regression analysis. The value of the $b$ slope in the length-weight relationship was 3.6971 and the intercept was 0.0031 . The prediction equations obtained for body moisture, crude protein, crude lipid and ash were, $y=71.680-0.404 B W, y=17.140-0.095 B W, y=8.432+0.364 B W$ and $y=3.720-0.032 B W$, respectively, where BW is the body weight of fish $(\mathrm{g})$. The use of prediction equations to describe body composition as a tool to support fish production and commercialization is suggested.
\end{abstract}

KEY WORDS. Aquaculture; fish; growth; mathematical modeling; regression analysis.

Systematic studies have shown that Astyanax Eigenmann, 1917 is represented by distinct species with controversial taxonomy (ReIs et al. 2003) and chromosomal plasticity (MedRADo et al. 2008). The genus comprises 92 valid species (BERTACO \& LuCena 2006, Melo \& BucKup 2006).

Mathematical models of fish growth offer an objective and practical way to describe growth and to estimate weight between sampling intervals. They may also offer accurate estimations of standing biomass and the amount of food needed for optimal fish production. Length and weight are standard data used in fish programs (CHERIF et al. 2008) to estimate growth rates (KOHLER et al. 1995). Length-weigh relationships allow conversion of growth-in-length into growth-in-weight in stock assessment models (Morato et al. 2001), estimation of biomass from length frequency distributions, estimation of fish condition (Petrakis \& STERgiou 1995), assessment of morphological characteristics of fish populations (STERgiou \& Moutopolous 2001) and maturity of individuals (Fafioye \& Oluajo 2005). The length-weight relationships in fish are important tools in aquaculture management.

Growth, defined as a change in scale, is one the most significant parameters in aquaculture. It can be measured as a function of size or tissue composition. Nutrition, genetics and health studies have recently started to focus more on fish body composition (Blanchet et al. 2005, Tobin et al. 2006), and given the increasing interest in fish quality and its nutritional value for human consumption (AzAm et al. 2004), the subject has been reviewed by various authors (Dumas et al. 2010,(MozAfFARIAN \& Rimm 2006, Kamal et al. 2007) . Despite the usefulness of lengthweight relationship and body composition, and the great economic importance of Astyanax aff. fasciatus to aquaculture in Brazil, this kind of information is laking for cultivated fish. This work aims to determine length-weight relationships and to elaborate prediction equations of body composition for cultivated Astyanax aff. fasciatus using regression analysis.

\section{MATERIAL AND METHODS}

The study was performed in the application unit of the Aquaculture Laboratory, Universidade Estadual de Ponta Grossa, Paraná, Brazil. Fish were obtained from a local fish farm (Piscicultura Águas Claras, Castro, Paraná, Brazil; 24²4'32"S and $\left.50^{\circ} 02^{\prime} 37^{\prime \prime} \mathrm{W}\right)$. A total of 300 fish were collected randomly between October 2011 and March 2012. Specimens are deposited in the Núcleo de Pesquisa em Limnologia, Ictiologia e Aquicultura/ Coleção Ictiológica at the Universidade Estadual de Maringá (NUP 11864), Maringá, Paraná, Brazil. Fish samples were obtained from two earth ponds, $300 \mathrm{~m}^{2}$ each. They were captured with surface and bottle trawl net (mesh size $=1 \mathrm{~cm})$, and were kept without food for $24 \mathrm{~h}$ before the beginning of the experiment. The latter was conducted in a 500-L indoor fiberglass tank aerated to main- 
tain dissolved oxygen of $>5$ and $<6 \mathrm{mg} / \mathrm{L}$. Fish were not fed artificial diets and given only natural food. Specimens were euthanized by overdose of benzocaine ( $3 \mathrm{~g} / 10-\mathrm{L})$, after which their total length and body weight $(0.01 \mathrm{~g})$ were measured individually $(0.1 \mathrm{~cm})$ and classified into five weight classes $(1.19 \pm$ $0.18,3.7 \pm 0.70,7.55 \pm 0.97,12.28 \pm 2.32$ and $22.16 \pm 2.64 \mathrm{~g}$ ), each containing three groups. Each treatment (weight class) consisted of 60 fish, which were divided into groups of 20 for the proximate composition analysis. Fish were minced and stored in a freezer $\left(-80^{\circ} \mathrm{C}\right)$ for later analysis of body composition.

The proximate composition analyses of fish samples were performed following AOAC (1990) procedures. Water content was determined by placing fish in a pre-weighed aluminum foil tray for drying in an electric oven at $55^{\circ} \mathrm{C}$ until constant weight and oven drying at $105^{\circ} \mathrm{C}$ for 24 hours; crude protein (nitrogen $x$ 6.25) was determined by the Kjeldahl method, after acid hydrolysis; lipid was extracted by petroleum ether in a Soxhlet apparatus followed by determination of lipid gravimetrically, and ash was determined by combustion at $550^{\circ} \mathrm{C}$, in a muffle furnace, until constant weight was reached.

Data on total length (L) in $\mathrm{mm}$ and body weight in $\mathrm{g}$ were recorded for each fish. The parameters $a$ and $b$ of the length to weight relationship were estimated using the logarithmic transformation of the equation: $W=a \times L^{\mathrm{b}}$, where $W$ is body weight, $g$ and $L$ length, $\mathrm{cm}$. The values of constant $a$ and $b$ were estimated from the log transformed values of length and weight $(\log \mathrm{W}=$ $\log a+\log \mathrm{L})$ via the least square linear regression. The average value of $b$ was tested to verify if it was significantly different from 3 using $t$-test at the 0.05 significance level. All statistical analyses were performed using the statistical package SPSS 14.0. The data on body composition were analyzed by one-way analysis of variance (ANOVA). Percentage data were transformed to arcsine values before analysis (ZAR 1996). The significance level was 0.05 . Prediction equations of the body composition of Astyanax aff. fasciatus were elaborated using linear $\left(\mathrm{y}_{\mathrm{i}}=\beta_{0}+\beta_{1} \mathrm{x}_{\mathrm{i}}\right)$ or second-order $\left(\mathrm{y}_{\mathrm{i}}=\beta_{0}+\beta_{1} \mathrm{x}_{\mathrm{i}}+\beta_{1} \mathrm{x}_{\mathrm{i}}^{2}\right)$ polynomial regression analysis (Zeilton et al. 1976).

\section{RESULTS}

The length-weight relationship was established through the equation $\mathrm{W}=0.0031 \times \mathrm{L}^{3.6971}\left(\mathrm{R}^{2}=0.9796\right)$ (Fig. 1). Mean percentages of moisture, crude protein, crude lipid and ash contents according to the body weight of Astyanax aff. fasciatus are presented in Table I.

All linear regressions resulted highly significant, with the coefficient of determination $\left(\mathrm{r}^{2}\right)$ ranging from 0.836 to $0.937(\mathrm{p}$ $<0.05$ ). The relationship between body moisture, crude protein and crude lipid and body weight was best expressed using linear regression analysis (Table II), and body composition can be expressed using the expressions: Moisture $=71.680-0.404 \mathrm{BW}$; Crude protein $=17.140-0.095 \mathrm{BW}$; Crude lipid $=8.432+0.364 \mathrm{BW}$; $\mathrm{Ash}=3.720-0.032 \mathrm{BW}$; where: $\mathrm{BW}$ is the body weight of fish (g).

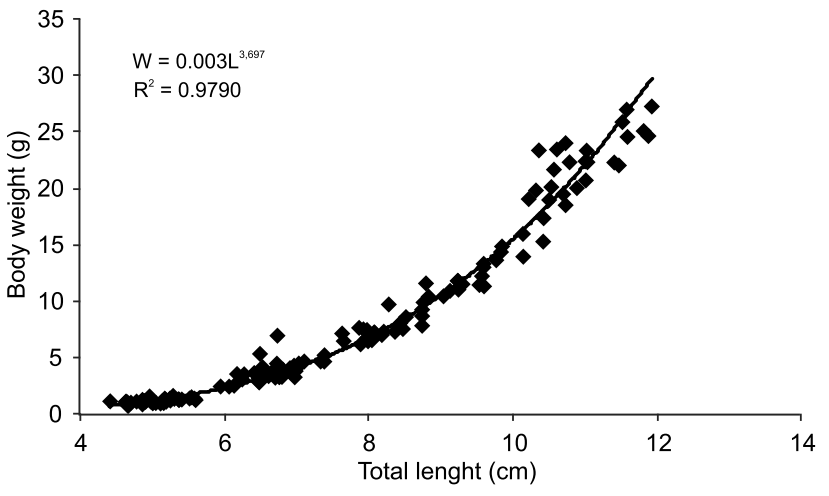

Figure 1. Length-weight relationship of market size cultivated female Astyanax aff. fasciatus.

Table I. Whole-body composition (mean + SD) of Astyanax aff. fasciatus according to body weight (\% wet weight basis).

\begin{tabular}{ccccc}
\hline \multirow{2}{*}{ Body weight $(\mathrm{g})$} & \multicolumn{5}{c}{ Body composition (\%) } \\
\cline { 2 - 5 } & Moisture & Crude protein & Crude lipid & Ash \\
\hline 1.190 & $72.05 \pm 0.22$ & $17.63 \pm 0.85$ & $7.16 \pm 0.19$ & $3.91 \pm 0.04$ \\
3.780 & $69.82 \pm 0.33$ & $16.74 \pm 0.79$ & $10.79 \pm 0.04$ & $3.48 \pm 0.08$ \\
7.558 & $68.5 \pm 0.21$ & $16.36 \pm 0.41$ & $11.42 \pm 0.18$ & $3.42 \pm 0.28$ \\
12.288 & $65.43 \pm 0.37$ & $16.86 \pm 0.62$ & $13.51 \pm 0.27$ & $3.19 \pm 0.03$ \\
22.160 & $63.25 \pm 13$ & $17.50 \pm 0.88$ & $15.12 \pm 0.19$ & $3.08 \pm 0.02$ \\
\hline
\end{tabular}

Values are the mean \pm SD of triplicate groups.

Table II. Statistical details showing number of fish studied (n), intercept $\left(\beta_{0}\right)$, slope $\left(\beta_{1}\right)$, p-value $(p)$ and correlation coefficient of cultivated Astyanax aff. fasciatus.

\begin{tabular}{ccccc}
\hline \multirow{2}{*}{ Item } & \multicolumn{4}{c}{ Body composition (\%) } \\
\cline { 2 - 5 } & Moisture & Crude protein & Crude lipid & Ash \\
\hline $\mathrm{n}$ & 60 & 60 & 60 & 60 \\
$\beta_{0}$ & 71.680 & 17.140 & 8.432 & 3.720 \\
$\beta_{1}$ & -0.404 & -0.095 & 0.364 & -0.032 \\
$\mathrm{P}$ & $<0.01$ & $<0.01$ & $<0.01$ & $<0.01$ \\
$\mathrm{r}^{2}$ & 0.930 & 0.836 & 0.859 & 0.861 \\
\hline
\end{tabular}

\section{DISCUSSION}

Fish growth models follow the "cube law" and Fulton's condition factor or isometric factor $\left(k=\mathrm{W} / \mathrm{L}^{\mathrm{b}}\right)$, where $K=$ condition factor, $M=$ body mass, $L=$ body length, and the weightlength exponent $b=3$ (Gulland 1983), which assumes that body shape maintains a constant proportion to length (Weatherley \& Gill 1987). In the present study, $b$ (3.136) value significantly higher from 3 and this implies that the "cube law" cannot be applied to this species. 
In the present work, the effect of body weight $(\mathrm{p}<0.01)$ on whole body moisture, crude protein, crude lipid an ash was linear. As observed by many authors, when fish grows in size, it deposits relatively more fat than other tissues (SAlam \& Davies 1994, SALAm et al. 2001). The distribution of body components among the various organs and tissues of the body may also show considerable differences (Weatherly \& Gill 1987). However, whole body composition varies in a similar manner among species as fish size increases (Lupatsch et al. 2001, Dumas et al. 2010). The live weight of fish, as a rule, consists of about 70 to $80 \%$ water, 20 to $30 \%$ protein and 2 to $12 \%$ lipid (Love 1980).

Body composition of fish is affected by several factors, including fish species (Alı et al. 2005), environmental variables (Ali et al. 2001), dietary factors and body size (EBrahimi \& OURAJI 2012). Information about fats, protein and mineral composition of fish in relation to size is important for consumers and facilitates the selection of species having the highest protein content at specific size (Ali et al. 2005). This is important because fish is one of the main sources of protein for humans in developing countries (Louka et al. 2004).

Percentage of moisture is a good indicator of the relative contents of total body energy, proteins and lipids (ALI et al. 2005). The lower the percentage of moisture, the greater the percentage of lipids and higher the energy density of fish (DEMPSon et al. 2004). In the present work, a highly significant linear increase was found between body weight and fat content (based on wet and dry weight), but moisture and crude protein content linearly decreased with an increase in body weight. This result is in agreement with the findings reported by SALAm et al. (2001), who observed that the fat content of Nile tilapia increases with fish size.

Condition factor is considered one of the important factors influencing body composition in fish (SALAm \& Davies 1994). But the condition factor is not always proportional to the cube of its length (WeAtherley \& Gill 1987) and can pose problems in the interpretation of obtained values. YousAf et al. (2011) found no significant difference between the body components of male and female Wallago atu Wallago attu Bloch \& Schneider, 1801. In Brazil both sexes of Astyanax aff. fasciatus are commercialized together and the market size of fish is related only to weight.

The importance of meat quality in animal production with respect to the requirements of specific markets was previously addressed by McMEeKAN (1941). He also commented on the technical difficulties, time and high cost associated with chemical analysis, emphasized the need to develop mathematical equations, and proposed linear regression equations to predict fat, muscle and bones in pigs. His results are in agreement with MemIs et al. (2006), who concluded that body elements can be estimated from fish weight using the predictive regression models developed in this work with a reasonable amount of accuracy.

In conclusion, the body composition of Astyanax aff. fasciatus varies according to body weight and body weight can be estimated by length-weight relationships. Body composi- tion can be estimated by prediction equations of linear regression analysis.

\section{LITERATURE CITED}

Ali, M.; A.Salam \& F. Iqbal. 2001. Effect of environmental variables on body composition parameters of Channa punctata. Journal of Research Science 12 (2): 200-206.

Ali, M.; F. Igbal; A. Salam; S. Iram \& M. Athar. 2005. Comparative study of body composition of different fish species from brackish water pond. International Journal of Environmental Science and Technolology 2 (4): 359-364.

AOAC. 1990. Official Methods of Analyses. Washington, Association of Official Analytical Chemists, vol. 1, $11^{\text {th }}$ ed., 1141p.

Azam, K.; M.Y. Ali; M. Asaduzzaman; M.Z. Basher \& M.M. Hossain. 2004. Biochemical Assessment of Selected Fresh Fish. Journal of Biological Sciences 4 (1): 9-10. doi: 10.3923/ jbs.2004.9.10

Bertaco, V.A. \& C.A.S. Lucena. 2006. Two new species of Astyanax (Ostariophysi, Characiformes, Characidae) from eastern Brazil, with a synopsis of the Astyanax scabripinnis species complex. Neotropical Ichthyology 4 (1): 53-60. doi: 10.1590/S1679-62252006000100004

Blanchet, C.; M. Lucas; P. Julien; R. Morin; S. Gingras \& E. Dewailly. 2005. Fatty acid composition of wild and farmed Atlantic salmon (Salmo salar) and rainbow trout (Oncorhynchus mykiss). Lipids 40 (5): 529-531. doi: 10.1007/s11745-005-1414-0

Cherif, M.; R. Zarrad; H. Gharbi; H. Missaoui \& O. Jarboui. 2008. Lenght-weignt relationships of 11 fish species from the Gulf of Tunis (SW Mediterranean Sea, Tunisia). Pan-American Journal of Aquatic Sciences 3 (1): 1-5.

Dempson, J.B.; Z.C.J. Schwar; M. Shears \& G. Furey. 2004. Comparative proximate body composition of Atlantic salmon with emphasis on parr from fluvial and lacustrine habitats. Journal of Fish Biology 64 (5): 1257-1271. doi: 10.1111/j.0022-1112.2004.00389.x

Dumas, A.; J. France \& D. Bureau. 2010. Modeling of growth and body composition in fish nutrition: where have we been and where are we going? Aquaculture Research 41 (2): 161181. doi: 10.1111/j.1365-2109.2009.02323.x

EвRAHIm, I.G. \& H. Ouraji. 2012. Growth performance and body composition of kutum fingerlings, Rutilus frisii kutum (Kamenskii, 1901), in response to dietary protein levels. Turkish Journal of Zoology 36 (4): 551-558. doi: 10.3906/ zoo-1008-139

Fafioye, O.O. \& O.A. Oluajo. 2005. Length-weight relationships of five fish species in Epe lagoon, Nigeria. African Journal of Biotechnology 4 (7): 749-751. doi: 10.5897/AJB2005.0003136

GulLAND, J.A. 1983. Fish stock assessment: a manual of basic methods. Chichester, Wiley Interscience, FAO/Wiley Series on Food and Agriculture, vol. 1, 223p. 
Kamal, D.; A.N. Khan; M.A. Rahman \& F.Ahamed. 2007. Biochemical composition of some small indigenous fresh water fishes from the river Mouri, Klulna, Bangladesh. Pakistan Journal of Biological Sciences 10 (9): 1559-1561. doi: 10.3923/pjbs.2007.1559.1561

Kohler, N.; J. Casey \& P. Turner. 1995. Length-weight relationship for 13 species of sharks from the western North Atlantic. Fishery Bulletin 93 (2): 412-418.

Louka, N.; F. Juhel; V. Fazilleau \& P. Loonis. 2004. A novel colorimetry analysis used to compare different drying fish processes. Food Control 15 (5): 327-334. doi: 10.1016/s09567135(02)00119-6

Love, R.M. 1980. The chemical biology of fishes. New York, Academic Press, 943p.

LupatshC, I.; G.W. Kissil \& D. SkLan. 2001. Optimization of feeding regimes for European sea bass Dicentrarchus labrax: a factorial approach. Aquaculture 202 (3-4): 289-302. doi: 10.1016/s004 4-8486(01)00779-7

McMeeran, C.P. 1941. Growth and development in the pig, with special reference to carcass quality characters. Part IV. The use of sample joints and of carcass measurements as indices of the composition of the bacon pig. Part V. The bearing of the main principles emerging upon the many problems of animal production and human development. The Journal of Agricultural Science 31 (1): 1-49. doi: 10.1017/S0021859 600048425

Medrado, A.S.; A.V.A. Figueiredo; A.M. Waldschmidt; P.R.A. Affonso \& P.L.S. CARNeIRo. 2008. Cytogenetic and morphological diversity in populations of Astyanax fasciatus (Teleostei, Characidae) from Brazilian northeastern river basins. Genetics and Molecular Biology 31 (1): 208-214. doi: 10.1590/s141547572008000200007

Melo, F.A. \& P.A. Buckup. 2006. Astyanax henseli, a new name for Tetragonopterus aeneus Hensel, 1870 from southern Brazil (Teleostei, Characiformes). Neotropical Ichthyology 4 (1): 45-52. doi: 10.1590/S1679-62252006000100003

Memis, D.; M.S. Celikkale \& E. ERcan. 2006. Effects of different diets on growth performance and body composition of Russian sturgeon (Acipenser gueldenstaedtii, Brandt \& Ratzenburg, 1833). Journal of Applied Ichthyology 22 (Suppl. 1): 287-290. doi: 10.1111/j.1439-0426.2007.00970.x
Morato, T.P.; P. Afonso; P. LouRINHo; J. BarReiros; R.S. SANTOS \& R.D.M. NASH. 2001. Length-weight relationship for 21 coastal fish species of the Azores, north-eastern Atlantic. Fisheries Research 50 (3): 297-303. doi: 10.1016/s0165-7836(00)00215-0

Mozaffarian, D. \& E.B. Rimm. 2006. Fish intake, contaminants, and human health: evaluating the risks and the benefits. Journal of American Medical Association 296 (15): 18851899. doi: 10.1001/jama.296.15.1885

Petrakis, G. \& K.I. Stergiou. 1995. Weight length relationships for 33 fish species in Greek waters. Fisheries Research 21 (3-4): 465-469. doi: 10.1016/0165-7836(94)00294-7

Reis, R.E.; S. Kullander \& J.R.C.J. Ferrari. 2003.Checklist of the Freshwater Fishes of South and Central America. Edicpucrs, Porto Alegre, $742 \mathrm{p}$.

Salam, A. \& P.M.C. Davies. 1994. Body composition of northern pike, Esox lucius L. in relation to body size and condition factor. Fisheries Research 19 (3-4): 193-204. doi: 10.1016/ 0165-7836(94)90038-8

Salam, A.; M. Ali \& M. Anas. 2001. Body composition of Oreochromis nilotica in relation to body size and condition factor. Journal of Research Sciences 12 (1): 19-23.

Stergiou, K.I. \& D.K. Moutopoulos. 2001. A review of lengthweight relationship of fishes from Greek marine waters. Naga, The ICLARM Quarterly 24 (1-2): 23-39.

Tobin, D.; A. Kause; E.A. Mntysaari; S.A.M. Martin; D.F. Houlihan; A. Dobly; A. Kiessling; K. Rungruangsak-Torrissen; O.Ritola \& K. RuOHONEn. 2006. Fat or lean? The quantitative genetic basis for selection strategies of muscle and body composition traits in breeding schemes of rainbow trout (Oncorhynchus mykiss). Aquaculture 261 (2):510-521. doi: 10.1016/j.aquaculture.2006.07.023

Weatherley, A.H. \& H.S. Gill. 1987. The biology of fish growth. London, Academic Press, 443p.

Yousaf, M.; A. Salam \& M. NaeEm. 2011. Body composition of freshwater Wallago attu in relation to body size, condition factor and sex from southern Punjab, Pakistan. African Journal of Biotechnology 10 (20): 4265-4268. doi: 10.5897/ajb10.1903

Zar, J.H. 1996. Biostatistical Analysis. New Jersey, PrenticeHall, 662p.

ZeILTON, I.H.; D.E. UllREY \& W.T. MageE. 1976. Quantifying nutrient requirements for fish. Journal of the Fisheries Research Board of Canada 33 (1): 167-172. doi: 10.1139/f76-019

Submitted: 05.II.2014; Accepted: 21.X.2014.

Editorial responsibility: Vinicius Abilhoa 